\title{
Introduction to the Seminar on Lacan
}

\author{
KENNETH REINHARD
}

$\mathrm{W}$

hy does Alain Badiou begin the project of publishing his seminars with the year on Lacan? Badiou often names Lacan as one of his three primary "masters," along with Sartre and Louis Althusser; but Lacan is certainly more than just one of several influences in Badiou's intellectual development. In his 1991 essay "Truth: Forcing and the Unnameable," Badiou writes, "A contemporary philosopher, for me, is indeed someone who has the unfaltering courage to work through Lacan's anti-philosophy." ${ }^{1}$ For Badiou, it is not Sartre or Althusser or any other twentieth-century thinker, but Lacan whose challenges every contemporary philosopher worth his or her salt must confront. ${ }^{2}$ The present volume of Badiou's 1994-95 seminar, the culmination of his three-year study of modern anti-philosophy with the special case of Lacan, makes good on this assertion, and demonstrates that in these terms Badiou is truly a-perhaps the-contemporary philosopher of our time. ${ }^{3}$

As Badiou indicates in this statement, it is not exactly Lacan's work as a whole that he considers urgent for philosophers today (and in this seminar he is concerned exclusively with the later Lacan), but Lacan as an "anti-philosopher." The term "anti-philosophy" was first used by several French Counter-Enlightenment figures to describe their reactionary opposition to the philosophes, 
and Lacan takes it up, perhaps with a touch of irony, in the $1970{ }^{4}$ Badiou, in turn, repurposes the expression, while preserving some aspects of its Lacanian inflection; for Badiou, anti-philosophy is not the antithesis of philosophy, but a transhistorical mode of thinking and doing that is both critical of one or more key philosophical concepts (such as truth or the good) and proposes a kind of act that it regards as in excess of philosophy's conceptual horizon. Badiou's list of anti-philosophers thus involves figures conventionally included in the history of philosophy, such as Blaise Pascal, Jean-Jacques Rousseau, Friedrich Nietzsche, and Ludwig Wittgenstein, as well as thinkers whose work falls outside philosophy proper, such as Saint Paul and Lacan. But however inside or outside, antagonistic or sympathetic, the anti-philosopher may be vis-à-vis philosophy, the philosopher has much to learn from their encounter, which at the very least may assist philosophy in clarifying its own agenda through the challenges of this particularly vexing other. Anti-philosophy overlaps at points with philosophy's other two historical antagonists, sophistry and religion, but its methods and ends are distinct from theirs. Like ancient and modern sophistry, anti-philosophy is skeptical about truth; and like religion, anti-philosophy seeks meanings outside the organons of knowledge. But anti-philosophy is neither a technique of persuasion or deconstruction nor a hermeneutics of revelation or redemption. Most essentially, anti-philosophy aims at an act that it believes is an unconditioned break, a transformation without determination, a groundless leap into the new. There is of course an element of the performative in both sophistry and religion that at moments might seem to align them with anti-philosophy. The anti-philosophical act properly speaking, however, is not in the service of some other aim (such as persuasion or belief), but is purely for its own sake. And whereas sophistry and religion are philosophy's competitors and often explicit enemies, the encounter of philosophy and anti-philosophy is more complicated, at times like that of 
therapist and patient, at others, like hysteric and master, and at best perhaps like that of neighbors-occasionally mutually beneficial, but uneasy and requiring careful minding of borders. ${ }^{5}$ The philosopher is well-advised not only to tolerate anti-philosophy, but to study it, to take its critiques seriously (if not necessarily to heart), to look to anti-philosophy in order to clarify the topology of philosophy: what is proper to it, what is improper to it, and even perhaps what, to echo Lacan, is "extimate" to it-in philosophy more than philosophy.

Let us return to Badiou's statement that "a contemporary philosopher, for me, is indeed someone who has the unfaltering courage to work through (traverser sans faiblir; literally 'to traverse without weakening') Lacan's anti-philosophy." The term that Badiou uses in this statement, traverser, has a special Lacanian resonance, appearing in the well-known expression "to traverse the fantasy" which denotes a moment of subjective transformation or conclusion in an analysis-a moment of the act. ${ }^{6}$ For Lacan, the aim of psychoanalysis is not self-understanding, but for the subject to "traverse" into a new position in the topology of the Other, the position of the object in its fundamental fantasy, in an act which involves the "destitution" of the subject itself. Badiou's imperative that a contemporary philosopher must traverse Lacan's anti-philosophy would then urge us not merely to think it through and appropriate it, the way, for example, Continental philosophy has explored and absorbed the lessons of structural linguistics and anthropology. Rather, the traversal of Lacan implies something transformative for philosophy, a shift in its fundamental position or orientation in thought through the encounter with the work of this self-proclaimed anti-philosopher.

For Badiou, the essential philosophical ideas are the subject, truth, and being, and to "traverse" Lacan requires unflagging strength and the courage to rise to the real challenge that Lacan poses to these fundamental philosophical topics. Both Badiou and Lacan regard the subject not as the foundation of consciousness, but as 
something occasional and evanescent. But whereas for Lacan the subject is a vanishing point, merely a disturbance of the symbolic order represented by the petrification of one signifier in relation to the movement of the other signifiers, for Badiou the subject is a "rare" but real achievement, the local instantiation of a truth process, with which an individual may affiliate and thereby attain a kind of nonindividual immortality as a subject. ${ }^{8}$ Badiou frames Being and Event with discussions of Lacan, clarifying the similarities and differences between his and Lacan's positions on being and the subject. In the opening Meditation, Badiou aligns his fundamental decision on being-there is no "one"; "oneness" is a secondary operation performed on a primary multiplicity-with Lacan's assertion in his later seminars that there is only a process of "some oneness" (ya d'l'Un), and that psychoanalysts must resist the temptations of the metaphysical One, which, like the possibility of a sexual relationship, is the yearning for something "worse" (in Lacan's elaborate coinage, s' . . oupire, which we translate here as "yearsening"'). But in the closing Meditation of Being and Event, Badiou points out that whereas Lacan defines the subject as merely a gap or void, a "thing of nothing," in Hamlet's phrase, for himself it is being that is constituted by the void and its concatenations (or, in the mathematical language of ontology, the empty set). If Being and Event opens with a profound gesture of affiliation with the Lacanian project in terms of ontology, it concludes with a crucial distinction on the nature and significance of the subject. Yet on this point too Badiou is perhaps closer to Lacan than to most of his philosophical contemporaries, for whom the subject remains a metaphysical concept, irredeemably tied to essentialism and humanism.

Finally, whereas most anti-philosophers disparage the idea of truth and elevate the local effects of meaning in its place, Lacan never entirely abandons some notion of truth (even if in his later work he insists that it can only be "half-said") and dramatically 
devalues the category of meaning, which, as a function of the imaginary, he regards as an illusion of consistency closely linked to that of the ego. ${ }^{10}$ Although Badiou agrees with Lacan in distinguishing truth from both knowledge and meaning, truth for him is the originary and essential philosophical idea. Badiou's understanding of truth derives from Plato, but breaks with most traditional philosophical definitions of truth in terms of correspondence, coherence, or pragmatic value, which Badiou refers to as "veridicality." For Badiou, truth is the emergence of something new in a world on the basis of what is most generic, hence most invisible and least localizable, within it. Truth is not a representation of the generic, but its extension. Truth is always produced under certain specific conditions depending on the realm of its production (art, politics, science, or love), but it is intrinsically trans-worldly, universal, infinite, and eternal. Badiou's philosophical accounts of truth, the subject, and being are all markedly different from Lacan's anti-philosophical accounts; but unlike other anti-philosophers, Lacan repurposes these concepts for psychoanalysis rather than merely rejecting them as unreal. And this makes Lacan a most unconventional and especially persistent anti-philosopher.

Lacan seems compelled to revisit the history of philosophy to an unusual degree for an anti-philosopher, and frequently berates the analysts in his audience for not doing likewise. For Lacan the obligation to read philosophy is not simply a question of "knowing your enemy," although there is certainly an element of that; rather, as Badiou points out, Lacan "puts philosophy to a test," seeks to ascertain whether philosophy has any purchase on the real or account of the act. ${ }^{11}$ Thus some of the singularity of Lacan as an anti-philosopher is due to the fact that he feels obligated not merely to reject philosophy, but as Badiou writes, to "traverse" it, endlessly probing its history for traces of the real-perhaps the way Doubting Thomas probes Christ's wounds in Caravaggio's painting - not only as the contrast 
to but also as the detritus of the decisive psychoanalytic act. ${ }^{12}$ Like Badiou, Lacan has a special affinity for Plato, the philosopher reviled above all others by most anti-philosophers. And Lacan's relationship to other anti-philosophers is not entirely positive; as Badiou writes, Lacan has "an anti-philosophical relationship to anti-philosophy itself." Hence we might say that for Badiou Lacan's work not only constitutes a key instance of modern anti-philosophy, but is itself the traversal of anti-philosophy, its subjective destitution, both fulfillment and dissolution. As such it also marks what Badiou calls the "closure" of modern anti-philosophy, the end of a certain formal and historical sequence. So it is clear why Lacan's anti-philosophy poses a singular challenge for Badiou and everyone who would be a contemporary philosopher, everyone, that is, who would contest the sophistic and hermeneutic claim of philosophy's death-that is, anyone who would ask, as Badiou does, what Lacan's anti-philosophy—the traversal and closure of a certain anti-philosophical sequence-opens up, for the philosopher willing to encounter it.

But what is distinctive about Lacan as an anti-philosopher? In what way is his critique of philosophy different from that of other modern anti-philosophers? Why does Badiou insist that Lacan is the single anti-philosopher with whom a contemporary philosopher must grapple; and why does this require "courage"?

Badiou begins the seminar by recapitulating the argument he had developed over the last few years that there are various distinct types of anti-philosophers, depending, on the one hand, on the different "subject matter" or materials on which they operate (that is, the particular realm of thinking that they endeavor to intervene in and transform) and on the other, on the different ways in which they locate and practice the all-important anti-philosophical act. For example, Nietzsche's subject matter and the material in which he makes propositions, according to Badiou, is "art," while his act is "archi-political," as expressed in his famous announcement, 
"We have just entered into great politics, even into very great politics ... I am preparing an event which, in all likelihood, will break history into two halves." ${ }^{13}$ That is, Nietzsche's medium is writing as creative invention, as rhetorical and poetic production; but the act that his entire life calls for is "archi-political," an intervention in the conditions or source of political action, in which he himself embodies a radical break in world history. In the case of Wittgenstein, the subject matter of his anti-philosophy, according to Badiou, is "language," understood as the material form of logical and conceptual construction, whereas his act is "archi-aesthetic," insofar as its central gesture is an act of showing or "letting-be" at the originary limit between the sayable and unsayable. ${ }^{14}$

Perhaps surprisingly, Badiou asserts that the material on which Lacan's anti-philosophy operates is "love" — rather than, as one might assume, jouissance or desire, which are arguably both more "material" than love for Lacan and more central to his theory and practice of psychoanalysis. In his earlier work, Lacan generally regards love as misrecognition, the result of transference, and connected with the imaginary aspect of the ego, but in his later thinking he assigns it a place of proximity to the real: insofar as love "makes up for the sexual relationship," whose impossibility comes to define the real for Lacan, love marks and holds open the place of that missing relationship. ${ }^{15}$ For Badiou, of course, love will come to be understood as one of the four "truth procedures" (along with politics, art, and science) that are the conditions of philosophy. ${ }^{16}$ Moreover, psychoanalysis is not just a theory, but a practice, something that takes place, and as such it seems to constitute an event in the truth procedures of love; as Badiou writes in his Manifesto for Philosophy, "In the order of love, of the thinking of what it conveys with respect to truths, the work of Jacques Lacan constitutes an event" (81). As we will see, one of the key elements of Lacan's critique of philosophy is that it puts a mere semblance of love (philo-sophia as the love of truth) at the center of 
its discourse. In doing so, according to Lacan, philosophy obscures the fact that, although love may be "imaginary," always transferential, merely a repetition, it nevertheless substitutes for something much worse: the illusion of the possibility of a sexual relationship. ${ }^{17}$

Lacan's anti-philosophical act, according to Badiou, is finally archi-scientific, an attempt to transform the relationship between knowledge, truth, and the real. Badiou cites Lacan's 1970 statement, "truth may not convince, knowledge passes in the act," as a key account of the act and its affiliation with knowledge rather than truth. Whereas most anti-philosophers regard the all-important act as a break with knowledge, whose value they minimize or relativize, for Lacan the act "passes" knowledge-which is not to say it "surpasses" knowledge, but on the contrary, that it transmits a kind of knowledge in the form of Lacanian "mathemes," by means of the particular psychoanalytic act known as "the pass." ${ }^{18}$ But the questions of what counts as this "passed" knowledge, its distinction from truth, and its embodiment in Lacan's mathemes are complicated, and will require a good deal of Badiou's attention in this seminar.

If, according to Lacan, philosophy seeks "knowledge about the truth of the real," it is because philosophy assumes that the real is the way things are, however that may be defined, and that there is an essential truth of this real, however complex that truth may be. Furthermore, philosophy sees knowledge as the attempt to establish the coherence of truth and its correspondence to the real, and to articulate it in meaningful and adequate representations. Badiou shows that for psychoanalysis-as-antiphilosophy there can be neither truth nor knowledge of the real. For Lacan the real is not an object with an essential truth that a subject can know, but a constitutive contradiction at the heart of subjectivity, a failed or missed encounter (the impossibility of a sexual relationship). Philosophy's fusion (or confusion) of knowledge, truth, and the real on the basis of these reflective correspondences resembles what Lacan calls the 
"imaginary tripod" of psychosis-the pseudo-symbolic structure that lends a fragile stability to the psychotic's delusions, temporarily forestalling complete breakdown. ${ }^{19}$ For Lacan the coherence of each of these dyads is illusory, and the three terms can only be understood as the irreducible strands of a Borromean knot in which no single term or link is self-sufficient. There is no representation adequate to the real, according to Lacan; it presents only the absence of meaning, or as he will put it in his 1972 essay "L'Étourdit," the real is "ab-sens," in excess of the philosophical opposition between sense and nonsense. ${ }^{20}$ The term "ab-sense" in Lacan (and what appears to be its equivalent, "ab-sex sense") signifies the absence or lack of a sexual relationship, the rock of the real on which subjectivity is both founded and founders.

So whereas most anti-philosophers champion the always local and contingent practices of meaning-making against the philosophical certainty that there can be global knowledge of the truth of the real, for Lacan there is indeed a kind of knowledge in the form of a matheme that can be integrally transmitted through an act-the pass - a knowledge that cannot be reduced to a meaning, is distinct from nonsense, and has nothing to do with truth. Furthermore, this knowledge can only emerge with the dissolution of the analysand's supposition of the analyst's knowledge, which structures the transference in the initial stages of an analysis. Truth is a problematic concept for Lacan, especially in his later work, where he argues that it has the linguistic structure of fiction or a lie, it is always incomplete and can only be "half-said" ${ }^{21}$ yet the very impossibility of its full symbolic articulation gives truth some purchase on the real. ${ }^{22}$ As Badiou points out, for other anti-philosophers there is usually something transcendent in the act, which reaches for a mystical or prophetic meaning beyond knowledge; for Lacan, however, the psychoanalytic act produces a knowledge that is both purely immanent and entirely transmissible. 
Badiou isolates three statements Lacan makes about philosophy in order to identify the critical elements of Lacan's idiosyncratic anti-philosophy: the claims that philosophy (1) is blocked by mathematics; (2) plugs the hole in politics; and (3) has love at the center of its discourse.

It is a common anti-philosophical complaint against philosophy that it is too enthralled by and dependent on mathematics, which anti-philosophers tend to consider as not really a mode of thinking at all, but merely the manipulation of signs. Modern anti-philosophers such as Nietzsche and Wittgenstein locate philosophy's primal error in the moment when, under the influence of Plato, it defined its project as continuous with the discoveries of mathematics and geometry. But Lacan's anti-philosophy is quite atypical in its assessment of mathematics: when Lacan says that philosophy is "blocked" by mathematics, according to Badiou, he does not mean that it is too much under its sway, but, on the contrary, that it has failed to fully comprehend mathematics. According to Lacan, philosophy is blinded to mathematics by its belief that the signs and formulas it uses are intended to discover or produce meanings linked to the world. Such a semantic or hermeneutical function is completely foreign to mathematics' real work, according to Lacan, which is based on purely axiomatic decisions. In Lacanian terms, mathematics is an act of "saying" (un dire) rather than a statement, a meaning that is "said" (un dit). Badiou agrees with Lacan's account of mathematics, at least on this point, but he will object that Lacan's critique of philosophy here is too sweeping: it is true that such a reduction of mathematics to semiotics is an ongoing temptation for philosophy but, Badiou insists, it is a temptation that philosophy also actively resists. Philosophy is always in the process of separating itself from religion, understood as the discourse of "meaning" par excellence; hence there is always some lingering trace of the hermeneutical that philosophy tries to eliminate from its thinking, and this may appear 
at times in the form of such misapprehensions about the nature of mathematics. But the originary philosophical gesture, according to Badiou, is to distinguish the truths that are its conditions from opinions and the encyclopedias of knowledge as such. And contrary to the suspicions of most anti-philosophers, philosophy's closest ally in this project is mathematics. In this sense, Badiou argues, philosophy can "unblock" mathematics, allow mathematics to realize its unique status as ontology.

Badiou's account of Lacan's critique of philosophy as "plugging the hole" in politics is more complicated and requires explication, in classic Lacanian fashion, in terms of the imaginary, the symbolic, and the real. There is a certain ambiguity in Lacan's formulations, moreover, as to whether there is a hole in politics that philosophy conceals or whether politics is itself a hole that philosophy obstructs with its metaphysical theorizations. First of all, Badiou points out that for Lacan philosophy fails to see that politics functions as an "imaginary hole in the real," a hole that functions, paradoxically, as a "glue" that produces solidarity in the face of capitalism's intrinsically fragmentary forces. This is indeed politics as denial of the real of capitalism, but it is also politics as shelter from or compensation for the trauma of that real; politics, in this sense, we could say, makes up for the impossibility of authentic human relations under capitalism. Secondly, Badiou shows that, in a sort of dialectical reversal of his first argument, Lacan also sees politics as a "symbolic hole in the imaginary," insofar as politics cannot be reduced to communitarianism, the imaginary coherence of the group, but involves "symbolic authorization" in a discourse, such as "collective will," beyond any organization based on individualism, a discourse that produces knowledge as a hole in the imaginary unity of the nation or state. Finally, Badiou demonstrates how politics for Lacan acts as a "real hole in the symbolic," as the de-completion of the impersonal order of political ideals and law. And here Badiou cites Carl Schmitt's 
theory of the sovereign decision on life and death as an example of such a "hole," the real exception that constitutes the symbolic law in the very process of exceeding it.

For Lacan, philosophy, beginning with Plato, has done nothing but obscure the nature of these political inconsistencies with theories that would grant politics one form or another of consistency. ${ }^{23}$ Badiou argues that for Lacan, on the other hand, the definitive political gesture is neither the foundational chartering of a collective nor the sovereign suspension of its laws, but the act of dissolving a group as such-a frequent occurrence in the history of Lacan's psychoanalytic associations themselves. For Lacan, a political organization is always contingent and temporary; it has a task to accomplish rather than a status quo to prolong, and the authentic political decision is the determination of the proper moment to liquidate the political structure that has served its purpose.

The third element Badiou points out in Lacan's critique of philosophy is the claim that philosophy puts love at the center of its discourse, in the form of the "love of truth." Badiou shows that for Lacan, when philosophy voices the superego-like command to "love truth," this is finally the imperative to love one's own impotence or symbolic castration as a speaking being, since truth is structurally incomplete, can only be "half-said" - the truth of the subject is its impotence. Philosophy promotes a lie about truth (that it is powerful) in order to conceal that truth is a lie, that it is limited by the conditions of linguistic structure, only available in the form of paradoxical spoken statements such as "I am lying." Badiou shows that for Lacan, philosophy could achieve a modicum of power by acknowledging that the truth it loves is merely a defense against its own impotence, and finally the lack of a sexual relationship as such, which it would prefer to know nothing about; only in this way could philosophy intervene in the all too human passion for ignorance. Philosophy has also erred, according to Lacan, in its promotion of 
happiness (which Lacan associates with "the American way of life") as the affect connected with truth. And Badiou agrees that happiness is both the aim of philosophy-although perhaps not in the "American" sense-and the affect of the truth procedure of love. ${ }^{24}$ For Lacan, however, what philosophy and American ego psychology call "happiness" is only a defense against jouissance and the anxiety that is its affect. As Lacan indicates, in a passage cited by Badiou, "the psychoanalyst holds his act in horror." 25 Instead of this impotent love of truth and pursuit of happiness, psychoanalysis, according to Lacan, involves the love of knowledge, a love that, in Lacan's aphoristic formulation, "raises impotence to the level of impossibility."

For Badiou, this is perhaps the single most precious of Lacan's many "verbal treasures," and one that he suggests, most remarkably, may also provide a precise definition of philosophy. Lacan articulates versions of this formulation at various points in his later work, including the summary of his $1971-72$ seminar, . . ou pire: "In psychoanalysis, it's a question of raising impotence (which accounts for the fantasy) to logical impossibility (which embodies the real)."26 Badiou argues that for Lacan philosophy loves and lingers in its own impotence, cherishing the fantasmatic cloaking whereby everyday castration, the limitations that we take on in acceding to the symbolic order, is accepted as an unavoidable "truth" of the human condition-an imaginary "realism" that philosophy prefers to the traumatic encounter with the real. Lacan takes a stand against impotence not by denying it (and proclaiming instead the reality of power, in the mode of Nietzsche) but by an act of "raising" or "elevating" impotence to the level of "impossibility" — which might seem even less potent. But whereas the "impotence" of castration involves a structure of fantasmatic compensation (finally, the unconscious belief in a fully potent Primal Father), "impossibility," as Lacan indicates, "embodies the real"-the real, precisely, as the impossibility of a sexual relationship. We may hear an echo in this 
formulation of "raising" of Lacan's account of the dynamics of sublimation in the196os, in which "the object is elevated to the dignity of the Thing." ${ }^{27}$ But the effective work of psychoanalysis as an act of "lifting up" something imaginary or symbolic (potency or impotence) to the level of the real (impossibility), does not have the "dignity" associated with the cultural work of sublimation. As Badiou points out, the psychoanalyst can only feel anxiety and "horror" at the prospect of this act. It cannot be faced with equanimity, insofar as it requires the analyst to enter into the place of the objet $a$, the wretched waste product of the analysand's act. Yet in neither case can this "lifting up" be reduced to the endless displacements and condensations of the unconscious, but involves an interruptive and transformative act, and the production of something new. Badiou uses Lacan's account of this elevation of symbolic "impotence" to real "impossibility" to schematize the movement of the analytic treatment: if the first phase of psychoanalysis involves a process of interpretation, in which the primal fantasy that accounts for the analysand's impotence is formalized as a movement of signifiers, the second phase occurs when an impasse in that work of formalization is encountered. Such a formal impasse, the impossibility of passage, is the condition of a real act; the work of the analyst is not to bring the analysand to the realization that an act or real change is "possible"-an act that is possible is, in fact, no act at all. An act that appears as possible in a given situation can only remain within that situation. Rather, it is only by demonstrating its impossibility, by reaching an impasse in interpretation, as if with one's back to the wall, that the "pass" of a real act can emerge.

Some readers may find elements of Badiou's reading of Lacan unorthodox, quixotic, or even outrageous, especially coming from someone who does not hesitate to confess that he is "unanalyzed," has never been either an analyst or an analysand. ${ }^{28}$ Badiou is not concerned about whether his ideas correspond with the doctrinal 
interpretations of one or another Lacanian school; he does not take a position about the various polemics that animate and divide them. Nor is Badiou interested in criticizing Lacan's anti-philosophy, although he points out what he takes to be limitations in some of Lacan's descriptive accounts of philosophy. Lacan's anti-philosophy is the only one that the philosopher really must work through, the only one that does not merely reject truth and knowledge, but rethinks their relationship with each other and to the real. The locus and matter of this thinking, according to Badiou, is love, and the philosopher cannot afford to ignore Lacan's evental irruption within the field of one of philosophy's four fundamental conditions. Finally, Lacan's project of elevating everyday impotence to real impossibility for the sake of a radically transformative act provides a working model for the intrepid philosopher of change. The philosopher who rejects the finitism and relativism of today's dominant ideology of what Badiou calls "democratic materialism" (ruled by the assertion that there are no truths, only bodies and languages) will find guidance and inspiration in Badiou's presentation of Lacan's singular anti-philosophy, and pointers towards a "materialist dialectic" which must encounter and traverse that impossibility. 
